\title{
Perspectives on Continuing Constitutional Activism: \\ The Case of the 1969-70 Arkansas Convention Delegates
}

\author{
Arthur English \\ University of Arkansas at Little Rock \\ John J. Carroll \\ Southeastern Massachusetts University
}

Abstract: Interviews with 80 of the 100 delegates to the 1969-70 Arkansas Comstitutional Convention demonstrate that the delegates have remained active on constitutional reform issues and constitute part of the state's attentive elite on these questions. The agenda of the 1979 Constitutional Convention is found to have been framed substantially by the terms of the 1970 debate. The reordering of priorities which does appear is the product of incremental constitutional reform since 1970 and the intrusion of national economic trends on the state. Delegates believe the major obstacles to constitutional change in Arkansas are public suspicion of change and the opposition of entrenched interest groups.

State constitution-making has been a frequent process in the United States. Since 1790 well over 200 constitutional conventions have taken place in the states, not to mention the thousands of amendments that have been proposed and adopted on a piecemeal basis. Arkansas has not been an exception to this trend. Since 1836 the state has had seven constitutional conventions and framed five constitutions. The existing constitution, written in 1874 , has been amended no less than 58 times. $^{1}$

Paralleling the frequency of constitution-making in the United States has been the intrinsic awareness, perhaps bred out of survival, of those directly affected by changes in a state's fundamental law - state officeholders, political parties, and interest groups - that constitution-making cannot be separated from politics. For some constitution-makers, namely those who drafted constitutions in the 1960 s and early 1970s, this was a hard and in some respects un- 
avoidable lesson to learn. The newness of the convention institution to these delegates and the myth that constitution-making was above politics, undoubtedly contributed to the defeat of the draft documents produced by several of these conventions. ${ }^{2}$ Ironically, John Roche and Robert Dahl have persuasively demonstrated that even the 1787 Constitutional Convention was an exceedingly politicized body where the basic norms of the American political process - persuasion, negotiation, and compromise - were hear. ily relied upon by the delegates and essential to the emergence of the United States Constitution. ${ }^{3}$

At the state level the statesman or ideal model of constitution-making is even more removed from political reality. There, powerful interest groups, executive-legislative rivalry, and state judiciaries, which are often enmeshed in the political process, make constitution-making easily susceptible to politicization.

The early 1960s saw an increased interest in constitutional revision by convention after a decline in the convention method during the previous 25 years. This resurgence in comprehensive constitution-making was stimulated by several factors: the Supreme Court's landmark reapportionment decision in Reynolds . Sims (1963), the ability of good government groups to awaken interest in constitutional reform, and the general drive to modernize state constitutions in order to confront increasingly complex governmental problems.

The literature on constitutional conventions correspondingly began to grow with the increased use of the convention institution. Scholars began to realize that constitutional conventions were interesting governmental phenomena that could yield useful insights about state government and that constitutional conventions could be analyzed empirically. Prior to the 1960s the literature on constitutional conventions was largely normative and prescriptive in nature. The state government textbooks of that period treated state constitutional conventions essentially from a legalistic and historical perspective. ${ }^{4}$ The literature addressed itself to what kind of a document a constitutional convention ought to produce. ${ }^{5}$ Little attention was given to the internal processes of the convention or its external environment.

The only exception to this trend was Vernon A. O'Rourke and Douglas W. Campbell's study of the 1938 New York State Conven- 
tion. Constitution-Making in a Democracy: Theory and Practice in New York State. ${ }^{\circ}$ This work, however, was still primarily a descriptive analysis of the New York Convention with no use of quantitative data. The more rigorous empirical work began with Albert Sturm's landmark study of the 1961-62 Michigan Constitutional Convention.? In this piece Sturm used survey research to collect delegate demographic and attitude data while also analyzing convention roll calls to calculate levels of party cohesion on some of the more important issues before the convention.

In an important article on the same convention, Robert S. Friedman and Sybil L. Stokes through delegate interviews investigated the relationship between statesman-like attitudes toward constitution-making and actual delegate behavior." They found that although the delegates admitted that constitution-making was on a higher plane than ordinary legislative policy considerations. voting behavior in the convention was still markedly partisan. In another informative article which analyzed the political context of state constitution-making. Lewis Froman found that the length of the state constitution and the number of times that amendments were proposed and adopted varied directly with the strength of a state's interest group system. ${ }^{\circ}$

Most of the recent empirical and theoretical work on state constitution-making has come from Elmer E. Cornwell, Jay S. Goodman, and Wayne R. Swanson's massive study of constitutional conventions during the 1960s and early 1970s. Cornwell and his associates studied conventions in Rhode Island, Maryland, New York, Illinois, Hawaii, New Mexico, and Arkansas.

The Cornwell group employed a broad conceptual model organized around the tension between reform and status quo forces in the constitution-making process. Through personal interviews conducted with the delegates at the beginning and end of those conventions, the Cornwell study accumulated a wide range of data on delegate demographic attributes, attitudes toward constitution-making. convention leadership patterns, delegate voting behavior, the role of parties and interest groups, and the ratification process. The Cornwell group's work has led to a spate of articles, monographs, and doctoral dissertations on the state constitution-making process and individual state conventions ${ }^{10}$ as well as a study on the practical considerations of organizing a 
constitutional convention and writing a document that will win approval. ${ }^{11}$ The culmination of the Cornwell work was a comparative volume entitled State Constitutional Conventions: The Politics of the Revision Process in Seven States. ${ }^{12}$

The literature on constitution-making in Arkansas seems to have commensurately expanded with recent constitutional reform efforts in the state. In the early 1960s Ralph Barnhart, in a speech which was later published in the Arkansas Law Review and Bar Association Journal, ${ }^{13}$ detailed the inadequacies of the existing 1874 Constitution in what was an important call for constitutional reform in Arkansas. Walter Nunn in a similar vein wrote of the inherent negativism in the 1874 Constitution and the restraints it placed upon government. ${ }^{14}$

Reform efforts in the $1960 \mathrm{~s}$ by public notables and several legislators referred to as the "Young Turks" supported by the state's first Republican Governor since reconstruction, Winthrop Rockefeller, finally resulted in the call of the 1969-70 Constitutional Convention. This convention was comprehensively studied ${ }^{15}$ by a group at the University of Arkansas at Little Rock led by Calvin R. Ledbetter. The Ledbetter group replicated the Cornwell methodology in assessing convention voting, leadership, demographic patterns, and the reasons for the defeat of the document produced by the convention. Another excellent study of the 196970 Constitutional Convention was done by Walter Nunn and Kay G. Collett. Their work is an insiders' view which systematically analyzed the forces leading to the convention call, the organization of the convention, and the defeat of the draft constitution. ${ }^{16}$

The defeat of the 1970 constitution did not quell the call for constitutional reform in the state. The question of whether another constitutional convention should be called to modernize state gorernment remained at the top of the state's political agenda throughout the 1970s despite the adoption of several constitutional amendments that were part of the $1970 \mathrm{draft}$ constitution. Indeed, these adoptions seemed to suggest that public attitudes toward constitutional reform were changing and that Arkansas would now support comprehensive reform. In particular, the call of the 1979 Arkansas Constitutional Convention following an earlier effort by only nine years presented an unusual opportunity for students of the state constitution-making process. 
The retrospective study of former delegates is an area of inquiry into state constitution-making that has been neglected by students and the reasons for this are not hard to find. Constitutional conventions are seldom held in a time frame which would allow researchers to obtain substantial feedback from former delegates on the current climate of constitutional reform. The last constitutional convention held in Arkansas, for example, was in $1918^{17}$ and while it would be very interesting to know what those constitution-makers think of current state constitution-making efforts, the time gap obviously makes such an effort unfeasible. Also, state constitutional revision usually takes place through the amendment process rather than by convention. This further limits the opportunity to obtain useful information on current constitutional reform efforts from former delegates.

\section{Questions for Analysis}

This project was begun with the view that an analysis of the 1969-70 delegates' experience with constitution-making would provide unique and valuable insight into subsequent constitutional reform efforts in Arkansas. The major hypothesis of this study is that the 1969-70 delegates remained an interested and active elite on behalf of constitutional reform in Arkansas who contributed to the call of the 1979 Arkansas Constitutional Convention. This is an interesting question for at least two reasons. First, how was the cause of constitutional reform kept alive after the defeat of the 1970 draft constitution? Given that convincing vote against comprehensive constitutional reform, why another constitutional convention was successfully called just nine years later remains as intriguing question. Second, an interesting hypothesis implicit in some of the recent literature on constitutional conventions suggests that the convention experience stimulates delegates to remain active in public affairs usually through the pursuit of other elective and appointed public office.

While data investigating this question were collected, they are not reported here. However, a related hypothesis is investigated by inquiring into the 1969-70 delegates' activity on behalf of constitutional reform. This offers a more unique and purer measure of delegate civic activity after the convention experience than the pursuit of public office where personal ambition is often a strong motivating force. Several other questions regarding the continuity 
of constitutional reform from the perspective of the 1969-70 delegates are also addressed in this study. Did the 1969-70 delegates look favorably on the call of the 1979 convention and did they work on its behalf? Why was the 1970 constitution not ratified and what can be learned from that experience? To what extent are the agenda of the two conventions the same? What advice can the former delegates offer the present constitution-makers on becoming more effective in their convention role?

\section{Method and Data}

To investigate these questions a mail and telephone survey of the 100 delegates to the 1969-70 Arkansas Constitutional Convention was conducted. The original survey instrument mailed to all 100 delegates in late August, 1978 consisted of a short cover letter explaining the study and its objectives and nineteen open and closed ended questions. The entire package was only four pages including the cover letter. A postage paid, self-addressed envelope was included to prompt delegate responses. This mailing resulted in 46 responses. In late November the same questionnaire was sent to all of the delegates who did not respond to the first mailing. The only difference between this and the first mailing was a shorter cover letter personally addressed to each delegate rather than "Dear delegate." This mailing resulted in 17 additional replies for a total of 63 respondents by mail.

In June, 1979 one of the principal investigators and a research assistant attempted to interview by telephone all of the delegates who had not responded. Again, the nature and objectives of the study were briefly explained to each delegate and the same survey instrument was used. Every delegate reached except one granted an interview, which averaged about 20 minutes. Telephone interviews were completed with 17 delegates for a final tally of 80 delegates or 84 percent of the potential respondents. ${ }^{18}$ Inspection of the data revealed no significant differences in the response levels and the general content of the responses between the two mail surveys and the telephone interviews.

The evidence reported in this study represents only a portion of the data collected and is geared to the continuing interest and activity of the 1969-70 delegates on behalf of constitutional reform and the continuity between the 1969-70 and 1979 Constitutional Conventions. Evidence on delegate public service career patterns 
and attitudes toward state constitution-making is to be reported in another paper. Since most of the data collected for this study was obtained from the analysis of open-ended questions, the data analysis has been limited to the reporting of frequency distributions.

\section{Continuing Delegate Satisfaction and Interest}

As a point of departure for this study, the 1969-70 delegates were asked if they were still satisfied with the constitution they had written despite its failure to achieve popular ratification. In interviews conducted immediately after the 1969-70 convention 198 delegates responding), 93 of the delegates had reported their satisfaction with the draft constitution and 98 of the 100 delegates had supported it on the final convention vote. ${ }^{19}$ What is interesting about the data reported in Table 1 is that 80 percent of the responding delegates still indicate satisfaction with the 1970 constitution. Thus, despite some expected erosion of support after nine years, a large number of former delegates still held positive feelings for the document thes had drafted.

\section{Table 1}

Were you satisfied with the document?

\section{YES NO}

$79 \% \quad 16 \%$
No Response

$5 \%$
$\mathrm{N}=80$

Why was a substantial majority of the delegates still positive toward a document written nine years ago? An analysis of the volunteered responses of the 1969-70 delegates suggests several explanations for their continued endorsements of that effort. First, the delegates viewed the 1970 draft as a substantial and needed improvement over the 1874 Constitution. Some of their comments on this point: "The new document was badly needed;" it was "a real improvement over the existing constitution." Second, the 1970 draft still appears to the delegates to have been a good compromise document. Their observations to this effect: it was "a sensible compromise," it was "the best compromise of 100 delegates;" "a compromise document, but it provided governmental flexibility;" "although a compromise document, it represented a step forward;" "not perfect, but acceptable." A related idea was that the 
document was the best that could be produced at the time: "good document on balance;" "best we could do at the time;" and "o.k. document, well balanced and mildly progressive." Delegate opinions, then, even with the benefit of nine years of retrospection, remained supportive of the 1970 document and its improvement over the 1874 Constitution.

\section{Table 2}

Have you maintained your interest in state constitutional issues since your service as a delegate?

\section{YES}

$86 \%$
NO

$14 \%$

Table 2 reports data on whether the 1969-70 delegates retained their interest in state constitutional issues since their convention experience. Delegate responses suggest support for the proposition that the 1969-70 delegates would maintain their interest in state constitutional issues with 86 percent of the surveyed delegates indicating continued interest. Table 3 presents more particular evidence on the question of continuing delegate interest in constitutional reform. Interestingly, despite the frustration of seeing the 1970 draft constitution defeated at the polls, 84 percent of the former delegates continued to view the convention process as "a good way to modernize Arkansas government." Only nine percent expressed disapproval of the convention process, while another seven percent were unsure.

\section{Table 3}

Do you think that a constitutional convention is a good way to modernize Arkansas's government?

YES

$84 \%$
NO

$9 \%$
Not Sure

$$
7 \%
$$$$
\mathrm{N}=80
$$

\section{Table 4}

Do you support the call of the ' 79 convention?

$\begin{array}{ll}\text { YES } & \text { NO } \\ 83 \% & 16 \%\end{array}$

No Response

$1 \%$

$\mathbf{N}=80$

While this evidence does not necessarily indicate that the 
1969-70 delegates believe that constitutional revision by amendment is a poor way of "modernizing Arkansas government," the data do suggest that the 1969-70 delegates had not lost faith in the convention institution as a means of constitutional reform and that they may perceive the present political context in Arkansas as supportive of such reform. Another measure of continuing delegate interest in constitutional reform reported in Table 4 is whether the former delegates supported the call of the 1979 convention. Again, a substantial majority of the responding delegates, 83 percent, supported the call while only 16 percent did not. However, these data are rather passive indicators of delegate interest and continuing activity.

\section{Past and Continuing Delegate Activity}

The evidence presented in Table 5 directly addresses the question of continuing delegate activity. One of the common assumptions regarding the failure of new constitutions to win approval is that delegates, believing that their responsibilities are over, do little to support the document during the ratification campaign. In essence, delegate nonsupport is often advanced as an explanation for the defeat of new constitutions. Yet the experience of constitutional conventions during the 1960s and early 1970s suggests this is a fallacious and oversimplified way of explaining the defeat of constitutions written by conventions.

Ratification campaigns on behalf of new constitutions involve many variables and, if anything, the past experience of constitution-making by convention shows that delegate endorsement and actual campaign support is usually present, but is only a minimal requirement for ratification. In particular, given the unexpected defeat of the 1970 document, did the former delegates perceive a failure on their part to work for the document? Did they believe that once the convention had adjourned their responsibilities had been met? Can delegate nonsupport be legitimately advanced as a reason for the defeat of the 1970 constitution?

The data in Table 5 report the delegates' perception of their work effort during the 1970 ratification campaign. These data indicate that post-convention complacency was not the norm among the 1969-70 delegates. Forty-four delegates, or 55 percent, indicated that they had "worked hard" on behalf of the new con- 
stitution, and an additional 35 percent said they had toiled "moderately" for it. Only three delegates reported that they had expended "very little" effort on behalf of the new constitution.

Interestingly, only two delegates indicated that they did not see the post-convention campaign as part of their responsibilities. In sum, the delegates' perception of their own role demonstrates that a substantial majority not only expected to participate actively in the ratification campaign but also worked hard on behalf of the new constitution.

\section{Table 5}

Delegate Perception of Work Effort on Behalf of Document Ratification

$$
\mathrm{N}=80
$$

Worked hard on behalf of new constitution

Worked moderately on behalf of new constitution

Worked very little on behalf of new constitution

Did not see it as part of responsibility

Worked against document

No response

What kind of work did the delegates specifically do on behalf of the 1970 constitution? Virtually all of the delegates who responded to this question said that they had made speeches to various civic clubs and community organizations. This was by far the most common form of delegate activity during the ratification campaign, and from our interviews it is clear that most of this activity took place in the delegates' home counties, at the grassroots where presumably it would do the most good.

Delegate activity was not merely limited to speeches however. About 15 percent of the respondents indicated they had paid for newspaper advertisements on behalf of the new constitution. Other delegates went on radio and television to speak for the new constitution. Several of the delegates who indicated that they worked "moderately" during the ratification campaign said they accepted any invitation to speak on behalf of the new constitution but that few invitations were forthcoming. What is particularly instructive for the 1979 constitutional convention delegates is that even allowing for the fact that time frequently enhances an individual's perception of effort, the 1969-70 delegates appear to have 
done a good deal of what was expected of them in support of ratification and still the document failed.

The failure of the 1970 constitution to win ratification did not terminate constitutional reform efforts in the state. In fact, it may be advanced that the unfinished agenda of constitutional reform was a key factor in keeping many of the former delegates involved in constitutional issues in the last nine years. The data in Table 6 are instructive. The data show that the most common form of delegate activity on behalf of constitutional revision since 1970 was the discussion of constitutional issues with friends and colleagues. At the elite level, almost two thirds of the 69 responding delegates had talked with local officials and 43 percent reported contacts with legislators concerning constitutional revision. One delegate belonged to several groups promoting constitutional reform, another introduced a bill for the new convention call, and two delegates had assisted in the preparation of Amendment 55 which dramatically reorganized county government in Arkansas.

\section{Table 6}

Delegate Activity on Behalf of State

Constitutional Revision Since 1970

$$
\mathrm{N}=69
$$

Testified before legislature

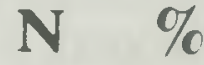

Attended regional seminars

Wrote to editor of newspaper

Contacted members of legislature

Talked to friends or colleagues

Contacted local officials

$65 \quad 94$

Campaigned for calling of '79 Convention $\quad 17 \quad 25$

Other

$10 \quad 14$

Also, as the possibility of comprehensive constitutional reform grew brighter during the 1970s, it apparently had the effect of stimulating some former delegates to work toward the call of a new constitutional convention. A full quarter of the responding delegates, for example, said they actively campaigned for the call of a 
new constitutional convention and 32 percent indicated they had attended regional seminars initiated to stimulate further interest in the newly called constitutional convention and to recruit candidates for delegate positions. Furthermore, nine of the former delegates ran for the 1979 constitutional convention and five were elected, including Robert A. Leflar, who served as President of the 1969-70 Constitutional Convention, and was elected President of the 1979 Constitutional Convention.

One delegate elected to the 1979 Constitutional Convention, Jim Brandon, probably qualifies as the most ardent proponent of constitutional reform in terms of sheer activity. Brandon was one of the original "Young Turks" and also served in the 1969-70 convention. Interestingly, several of the delegates elected to the 1979 convention were children of former delegates and one 1979 delegate was the grandson of a 1969-70 delegate. ${ }^{20}$ In sum, this represents a broad range of activity on behalf of constitutional reform by the 1969-70 delegates, and while a precise measure of their influence upon the call of the 1979 Constitutional Convention cannot be determined, it appears clear that the former delegates constituted an important part of the elite public on constitutional reform during the 1970s.

Given their previous experience and their continuing interests, it was appropriate to ask the former delegates what they believed should be the major issues before the new convention. These responses are tabulated in Table 7 where they are compared to the issues which these same delegates believed most important in the 1969-70 convention. The similarity of the two agendas is striking. The only items not to appear on the 1979 agenda are the bill of rights, suffrage and elections, and the amending process, none of which had high salience in 1970. However, the 1979 agenda does have somewhat different emphases. In comparison to 1970 , there seems to be a lessened emphasis on the structural reform of government. Only judicial reform has risen in salience, while executive, legislative and local government have all declined, the latter two substantially. 


\section{Table 7}

Comparison of 1970 Delegates'

Perception of Agenda Salience

for '70 and '79 Conventions

1970

Agenda Item

Executive

Local Government

Judicial

Finance, Taxation \&

Revenue

Legislative

Right to Work

Usury

Amending Process

Suffrage \& Elections

Miscellaneous

Bill of Rights

Education

Total Replies $\mathrm{N}=445$

1979

$\begin{array}{clc}\begin{array}{c}\% \text { of } \\ \text { Mentions }\end{array} & \text { Agenda Item } & \begin{array}{c}\% \text { of } \\ \text { Mentions }\end{array} \\ 18 & \text { Usury } & 24 \\ 14.5 & \text { Judicial } & 17 \\ \text { Executive } & 13\end{array}$

11.5 Local Government 10

10 Municipal Finance 10

7.5 Taxes 8

6.5 Miscellaneous 6

4.5 Right to Work 5

3.5 Legislative 4

3.5 Education 2

1 Gambling 1

1

Total Replies $\mathrm{N}=140$

Table source: Elmer E. Cornwell, Jr. et al, State Constitutional Conventions: The Politics of the Revision Process in Seven States (New York: Praeger, 1975) p. 153.

Why the different emphases in agenda? The adoption of Amendments 55 and 56 had the effect of respectively removing the organization of county government and legislative and executive branch salaries from the current agenda. What is especially interesting in comparing the two agenda, however, is the emergence of usury as a central issue for the new convention. During the 1969-70 convention, usury was seen as an important and controversial issue although the existing usury and right-to-work provisions were retained in the draft document. With the advantage of hindsight, the 1969-70 delegates' decision not to change the usury provision seems to have reflected their pragmatic judgment that such a change would have jeopardized the ratification chances of 
the entire document and that the ten percent usury limitation was not a significant liability to the state's financial health.

In this context the change in the former delegates' attitudes toward the usury limitation is remarkable. Despite the overwhelming defeat of an amendment increasing the usury limitation in $1974^{21}$ and the possibility that a similar change might seriously impair the potential ratification of the new constitution, the 1969 70 delegates came to see usury as an unavoidable item for the 1979 convention. The changes in the 1979 agenda then reflect the incremental constitutional reforms adopted since 1970 and the inevitable impact of national financial trends on the state. One other point is significant in respect to the 1979 convention's agenda. The categories of local government, taxes, and municipal finance are clearly related and when collapsed into one item, they become the single most salient agenda item for the new convention according to the 1969-70 delegates. These related issue attitudes of the former delegates seem to reflect the unfinished municipal agenda of the 1969-70 convention and the continued concern among these delegates for greater local autonomy and flexibility in dealing with revenues and expenditures.

\section{The 1970 Constitution and The Defeat}

On February 10, 1970 the convention adjourned. The new constitution was presented to the voters in the general election on November 3 rd of that year. The draft constitution, presented as an all or nothing choice, was not an ultra-reform effort although some publics may have perceived it as such. It did, however, embody substantial reform over the existing 1874 Constitution. It expanded personal liberties, made the legislature a more professional and accountable body, strengthened and rationalized the executive branch, provided for a unified and rationalized judiciary, and allowed local governments greater autonomy. In a word, the 1970 draft constitution was a substantial step toward the modernization of Arkansas state and local government, modernization badly needed in the face of the increasingly complex private and public sector problems which have confronted state and local governments during the second half of this century.

Based on the National Municipal League's Model Constitution, ${ }^{22}$ however, the reform score of the 1970 constitution regis- 
tered 28 out of a possible 58 points. Since the 1874 Constitution already contained eight reform points, the actual reform distance traveled between the existing and proposed constitutions was 20 points or 40 percent which indicated a substantial status quo element was retained in the new document. Nevertheless, despite what apparently was an astute balance between reform and document maintenance, the draft constitution was soundly defeated: 223,334 (43 percent) votes for, 301,195 ( 57 percent) against.

What is particularly revealing and paradoxical about the defeat is that the new constitution appeared to have a good deal of support during the ratification campaign. First, virtually all the delegates endorsed the new constitution and, as the data indicated, worked hard at the local level on its behalf. Second, there was an active 'for group' which spent an estimated $\$ 150,000$ for television, radio, and newspaper advertisements that publicized the new constitution adequately throughout the state. Finally, the new document attracted a large number of blue-ribbon endorsements, and while more sound than substance, these endorsements were on balance more of an asset than a liability to the ratification campaign. Despite the difficulty of selling abstract constitutional reform to an electorate used to bread and butter issues and the failure of the 'for campaign' to catch on, the new constitution's dismal failure at the ballot box was a surprise to many. Although it has been a decade, several of the delegates still remarked that they were greatly surprised by the document's convincing defeat, expecially since most of the polls had predicted that the document would win approval, though by a slim margin. ${ }^{23}$

Table 8 reports the responses of the 1969-70 delegates to the question of why the document lost. Interestingly, the delegates' retrospective assessment of the 1970 constitution's defeat suggests that almost any substantial effort at constitutional reform at that time would have failed because of general citizen apathy and resistance to change. In particular, 21 percent of the total delegate mentions pointed to "voter apathy and lack of understanding," 12 percent indicated "resistance to change," and an additional 10 percent attributed the defeat to the "fear of new taxes." These data suggest a public unaware of the benefits of a new constitution and suspicious of change as the major reasons for defeat rather than 
more specifically designated causes, such as an ineffective ratification campaign, voting on a new constitution in a special rather than general election, or the electoral format within which the document was presented.

\section{Table 8}

Why was the 1970 Constitution defeated?

$$
\mathrm{N}=80
$$

\section{Response}

Public apathy and lack of understanding Resistance to change

Local government opposition

Interest group opposition

Fear of new taxes

General election instead of special Ineffective campaign

Miscellaneous

All or nothing election format

Too long a ballot

Number of \% Mentions

Too much lag time to ratification election 3

Delegates did not support document

Liquor industry opposition

Controversial issues

Usury

\section{Total}

The other major reason for the defeat of the 1970 constitution is also highlighted by the data: institutionalized interest group opposition. When this category is added to "local government opposition" it becomes the single most mentioned item as the cause of the defeat. The 1970 constitution contained provisions which frightened liquor and real estate interests, county officials and employees, and sitting judges. The decision of the convention not to deal with the right-to-work provision earned the new constitution at worse the opposition and at best the indifference of labor groups. The maintenance of the existing usury provision assured 
that the business community would not be a strong proponent of ratification. These were clear factors in the 1970 constitution's defeat as was, as one delegate put it, "the quiet but effective campaign" the county judges and employees conducted against the new constitution.

\section{Table 9}

How can the document produced by the 1979 Constitutional Convention win approval?

$$
\mathrm{N}=73
$$

\section{Response}

Be practical

Separate submission of proposals

Inform and educate public

Make changes only where needed

Run a strong campaign on behalf of document

Vote on document in special election

Miscellaneous

Write a constitution, don't legislate

Delegate commitment to work hard for document

Do a good job as a delegate

Avoid lawyers and academics as spokesmen

Don't run scared

Keep usury limitation low but provide for some flexibility

Total

Table 9 presents advice from the former delegates on the fundamental political question facing the 1979 constitutionmakers: How can the document produced win approval? The evidence indicates that the 1969-70 delegates have become very realistic and practical about constitutional reform in Arkansas. Their responses suggest that only constitutional reform which can be justified and explained to the people should be attempted by the
Number of \% Mentions

15 
new convention. They suggest that practicality and incremental change are easily defended and that this drafting strategy should be combined with vigorous campaigns designed to educate the public and to support ratification.

One interesting aspect of these data, especially in light of the former delegates' recalcitrance to attribute the defeat of the 1970 constitution to the 1970 electoral format, is the number of former delegates who now believe that certain structural arrangements in the ratification election would enhance the adoption chances of the 1979-80 draft constitution. In particular, they recommend the separate submission of controversial proposals would lessen the danger that well-organized opposition to a handful of highly salient issues might defeat the document as a whole. It might be recalled that the strategy of separate submission was successful in both Illinois and Hawaii. ${ }^{24}$ Second, they believe a special rather than general election might result in the turnout of more well informed voters and maximize the possibility of educating the public on the merits of the document. Thus, nine years after the defeat of the 1970 constitution, the former delegates believed that constitutional reform would be difficult to sell to the public and that no stone should be left unturned to assure passage of a new constitution.

Finally, the former delegates were asked what advice they would give to the present delegates to help them perform their jobs more effectively. The thrust of their observations was to give careful attention to the lessons of the past, to openness in convention processes, and to hard work. The continuity in agenda is particularly reflected in the most common observation of the 1969-70 delegates: that the new convention would save itself considerable work by referring to the existing constitution and the $1970 \mathrm{draft}$. At the same time, the 1979 delegates were instructed to keep the public informed, to keep an open mind, to be practical, and to be willing to compromise. A number of delegates also raised two classic concerns of constitution-making: (1) that the new convention write a constitution and not legislate and; (2) that the new document should not be excessively detailed so as to be adaptable to changing circumstances. Overall, many of the delegate comments seemed to touch upon the "idealist-realist" dimension of 
constitution-making which holds that while constitution-making is clearly something special, it is not above politics.

\section{Table 10}

What advice would you give to the new delegates to help them perform their job more effectively?

$$
\mathrm{N}=74
$$

\section{Response}

Numbers of \% Mentions

Study existing constitutions and earlier convention documents

Write a constitution, don't legislate Be willing to compromise Keep people informed

Be practical

Vote your convictions

Listen carefully

Keep an open mind

Attend convention meetings regularly

Work hard

$\begin{array}{rr}22 & 18 \\ 10 & 8 \\ 9 & 7 \\ 8 & 7 \\ 8 & 7 \\ 8 & 7 \\ 8 & 7 \\ 7 & 6 \\ 6 & 5 \\ 5 & 4 \\ 4 & 3 \\ 2 & 2 \\ 2 & 2 \\ 2 & 2 \\ 2 & 2 \\ 17 & 14\end{array}$

Study and deal with the issues

Specialize

Know who to ask for help

Keep local government officials informed

Obtain important committee assignments

Miscellaneous

120

\section{Conclusions}

Our analysis concludes that the delegates to the 1969-70 Arkansas Constitutional Convention remained active in the Arkansas political system as part of the attentive elite on constitutional reform. These delegates took a broad view of their responsibilities as delegates and bore much of the burden of the ratification campaign. Subsequent to the defeat of the $1970 \mathrm{draft}$, many delegates remained active on constitutional issues in a variety of ways and 
emerged in 1979 as substantial movers in the drive for a convention.

Given the continued activism of the 1969-70 delegates, it was not surprising to discover that the present agenda is framed to a considerable extent by the terms of the 1970 debate. The continuity is striking. The reordering of priorities which does appear is the product of incremental constitutional reforms initiated through the Arkansas legislature and the increasing impact of national economic trends on the states. Otherwise, the problems seem very much the same.

The major obstacles to constitutional reform seem to be the inherently abstract and complex nature of the constitution-making process, public suspicion of change, and the opposition of entrenched interest groups. The advice of the former delegates addresses this perception of the public mood and special interests. They urged the new convention to move cautiously and openly in order to offset public resistance. Their advice is pragmatic: "keep people informed," "work hard," "attend convention meetings," "be willing to compromise," "be practical". These are suggestions designed to buttress public confidence in the convention itself and weaken interest group opposition by instructing the new convention to produce a draft document which is not overly ambitious and is easily defended.

The 1969-70 delegates also suggest the use of safety valve techniques such as special election and separate submission of proposals as ways to maximize the ratification chances of a new constitution. Their advice is clearly oriented to obtaining as much constitutional reform as will be accepted without losing the whole document. Suspicion and opposition to constitutional reform are not confined to Arkansas. The majority of draft constitutions emerging from the spate of state constitutional conventions in the 1960's were defeated at the polls. The advice of the 1969-70 delegates seems designed to avoid a repetition of those historic experiences. 


\section{Notes}

Acknowledgments: The authors would like to thank Beadle Moore and Calvin R. Ledbetter for their helpful comments on an earlier draft of this paper. Thanks are also extended to Glenda Hale, Pat Stansberry and Donna English for typing the final manuscript and its earlier drafts.

1. Although the Arkansas Constitution has been amended more than 60 times, only 58 amendments appear in most copies. For a discussion of the amending process in Arkansas see Robert W. Meriwether, "The Amending Process," in Readings in Arkansas Government, Walter Nunn, editor (Little Rock: Rose Publishing Company, 1973), pp. 49-58.

2. During this period of time, draft constitutions were defeated in Rnode Island, Maryland, New York, New Mexico, and Arkansas.

3. John P. Roche, "The Founding Fathers: A Reform Caucus in Action," American Political Science Review, Vol. 55, No. 4 (December, 1961), pp. 799-816; Robert A. Dahl, Pluralist Democracy in the United States (Chicago: Rand McNally, 1967), pp. 26-55.

4. For a discussion of how this literature was treated see Arthur English and John J. Carroll, "Teaching Constitutional Conventions in Legislative Process and State and Local Government Courses," Teaching Political Science (forthcoming).

5. For an example of this approach see the Model State Constitution (New York: National Municipal League, 1921).

6. Vernon A. ('Rourke and Douglas W. Campbell, Constitution-Making in a Democracy: Theory and Practice in New York State (Baltimore: The Johns Hopkins Press, 1943).

7. Albert Sturm, Constitution-Making in Michigan, $1961-1962$ (Ann Arbor: Institute of Public Administration, 1963).

8. Robert S. Friedman and Sybil L. Stokes, "The Role of the Constitution-Maker as Representative," Midwest Journal of Political Science, Vol. 9, No. 2 (May, 1965), pp. 148-166. 9. Lewis A. Froman, Jr., "Some Effects of Interest Group Strength in State Politics," American Political Science Review, Vol. 60, No. 4 (December, 1966), p. 961.

10. See, for example, the following monographs: Leon S. Cohen et al., The Politics of the New York Constitutional Convention (New York: National Municipal League, 1969); Elmer E. Cornwell, Jr., and Jay S. Goodman, The Politics of the Rhode Island Constitutional Convention (New York: National Municipal League, 1973); Elmer E. Cornwell, Jr., and Jay S. Goodman, The Politics of the Rhode Island Constitutional Convention (New York: National Municipal League, 1969); Wayne R. Swanson, Elmer E. Cornwell, Jr., and Jay S. Goodman, Politics and Constitutional Reform: The Maryland Experience, 1967-68 (Washington, D.C.: Washington Center for Metropolitan Studies, 1970). Doctoral dissertations connected with the Cornwell project are Arthur English, "Constitution-Making in a Nonpartisan Setting: The New Mexico Experience, 1969-70," Brown University, 1975; Sean A. Kelleher, "The Politics of the Hawaii Constitutional Convention," Brown University, 1973; Charles R. Pastors, "Constitution-Making in Illinois: A Process of Traditional Politics," University of Chicago, 1972.

11. Elmer E. Cornwell, Jr., Jay S. Goodman and Wayne R. Swanson, Constitutional Conventions: The Politics of Revision (New York: National Municipal League, 1974).

12. Elmer E. Cornwell, Jr., Jay S. Goodman and Wayne R. Swanson, Constitutional Conventions: The Politics of the Revision Process in Seven States (New York: Praeger Publishers, 1975).

13. Ralph C. Barnhart, "A New Constitution for Arkansas," Arkansas Law Review and Bar Association Journal, Vol. 17, No. 1 (Winter, 1962-63), pp. 1-15.

14. Walter Nunn, "The Negativism of the 1874 Constitution," in Readings in Arkansas Government, Walter Nunn, editor (Little Rock: Rose Publishing Company, 1973), pp. 20-25.

15. Calvin R. Ledbetter, Jr., et al., Politics in Arkansas: The Constitutional Experience (Little Rock: Academic Press of Arkansas, 1972).

16. Walter Nunn and Kay G. Collett, Political Paradox: Constitutional Revision in Arkansas (New York: National Municipal League, 1973).

17. For an account of this convention see Abe Collins, "Reminiscences of the Constitutional Convention of 1917-18," The Arkansas Historical Quarterly, Vol. 1, No. 2 (June, 1942), pp. $117-123$ 
18. Of the 20 delegates we were not able to interview, four had died and one could not be interviewed because of serious illness. Of the remaining 15, most had moved and could not be traced by telephone. One delegate refused to be interviewed and several were called repeatedly but could not be reached.

19. We have computerized the responses of the 1970 delegates to the two rounds of interviews administered by the Cornwell group at Brown University. These data are taken from these files.

20. The 1969-70 delegates elected to the 1979 A rkansas Constitutional Convention were Jim Brandon, Don Davis, O.P. Hammons, Robert A. Leflar, and Henry Wilkins, 111. Clifford M. Cole, James Dailey, Jr., and Jay Eldridge are the sons of 1969-70 delegates and the grandfather of Allan Wren was also a 1969-70 delegate. Interestingly, three of these individuals told us in phone interviews that their relatives' convention service was strong factor in motivating them to run for the 1979 convention.

21. Proposed Amendment No. 57 was defeated by a vote of 66,905 to 426,197 against. Election Return Abstracts on File, Office of the Secretary of State.

22. Model State Constitution, revised edition (New York: National Municipal League, 1968).

23. Nunn and Collett, op. cit., p. 161.

24. See Cornwell et al., Constitutional Conventions: The Politics of the Revision Process in Seven States, op. cit., pp. 167-169, 173-176. 